\title{
Comparative genetics of sarcoid tumour-affected and non-affected mountain zebra (Equus zebra) populations
}

\author{
Sooryakanth P. Sasidharan ${ }^{1 *}$, Anette Ludwig ${ }^{1}$, Cindy Harper', Yoshan Moodley ${ }^{2}$, \\ Henk J. Bertschinger ${ }^{3}$ \& Alan J. Guthrie ${ }^{4}$ \\ ${ }^{1}$ Onderstepoort Laboratory for Applied Veterinary Genetics, Private Bag X04, University of Pretoria, Pretoria, 0110 South Africa \\ ${ }^{2}$ Cardiff School of Biosciences, Cardiff University, P.O. Box 915, Cardiff, CF103TL, United Kingdom \\ ${ }^{3}$ Veterinary Wildlife Unit, Private Bag X04, University of Pretoria, Pretoria, 0110 South Africa \\ ${ }^{4}$ Equine Research Centre, Private Bag X04, University of Pretoria, Pretoria, 0110 South Africa \\ Received 6 November 2008. Accepted 8 March 2011
}

\begin{abstract}
In recent years, South African conservation officials have noted the appearance of sarcoid tumour-like growths in Cape mountain zebra (Equus zebra zebra) populations. In domestic horses (Equus ferus caballus), a genetic predisposition for this bovine papillomavirusinduced tumour is reported. This investigation compared population genetic parameters within tumour-affected populations in Bontebok National Park and Gariep Dam Nature Reserve against Cape mountain zebra populations having few or no tumours in Karoo National Park and Karoo Nature Reserve in South Africa and Hartmann's mountain zebra populations from Namibia. Tumour-affected populations had the lowest levels of expected heterozygosity, gene diversity and polymorphism and highest values of internal relatedness and homozygosity by loci but not reaching levels of significance $(P=0.05)$. Wright's $F_{I s}$ values indicated an overall deficit of heterozygotes in both affected and non-affected Cape mountain zebra populations. Considerable population substructuring, as indicated by $\boldsymbol{F}_{\mathrm{ST}}$ values and Bayesian clustering, was revealed among all Cape mountain zebra populations. The results provide support for current conservation policies aimed at increasing levels of genetic diversity in isolated Cape mountain zebra populations.
\end{abstract}

Key words: Cape mountain zebra, sarcoid tumour, papillomavirus, inbreeding, genetics.

\section{INTRODUCTION}

The Cape mountain zebra (Equus zebra zebra) is among the most endangered mammals in South Africa and the world (Penzhorn 1979; Penzhorn \& Novellie 1991; Novellie et al. 2002). Cape mountain zebra populations in South Africa have multiplied from the brink of extinction in the 1930s (Bigalke 1952) to reach levels of around 1600 animals by 2004 (Friedman \& Daly 2004). All South African Cape mountain zebras are descended from no more than 30 individuals originating from three populations: from the Mountain Zebra National Park (MZNP), and the Kammanassie and Gamka Mountain Nature Reserves (Bigalke 1952). MZNP was established in 1937 near Cradock, with a founder population of five stallions and one mare. Most extant stock is derived from the few animals that survived and thrived in the Cradock region,

*To whom correspondence should be addressed. E-mail: soorya.sasi@gmail.com specifically within the MZNP and were later translocated to form new populations (Penzhorn 1988). The population at MZNP is currently maintained at around 300 to 400 animals and as many as 40 zebras are removed annually to reestablish breeding herds elsewhere within their original range (Penzhorn \& Novellie 1993). Animals have been translocated to a multitude of places, including six national parks, 10 provincial and 17 private reserves (Novellie et al. 1996; 2002). Disease outbreaks (Marais et al. 2007) and low inbreeding levels (Moodley 2002; Sasidharan 2004) have prompted imaginative and challenging proposals for the long-term population management of the entire zebra subspecies (Moodley \& Harley 2005; Watson \& Chadwick 2007; Smith et al. 2008).

A previous study investigated and described fibroblastic growths similar to equine sarcoids (Fig. 1) from two Cape mountain zebra populations in Bontebok National Park (BNP) and Gariep 


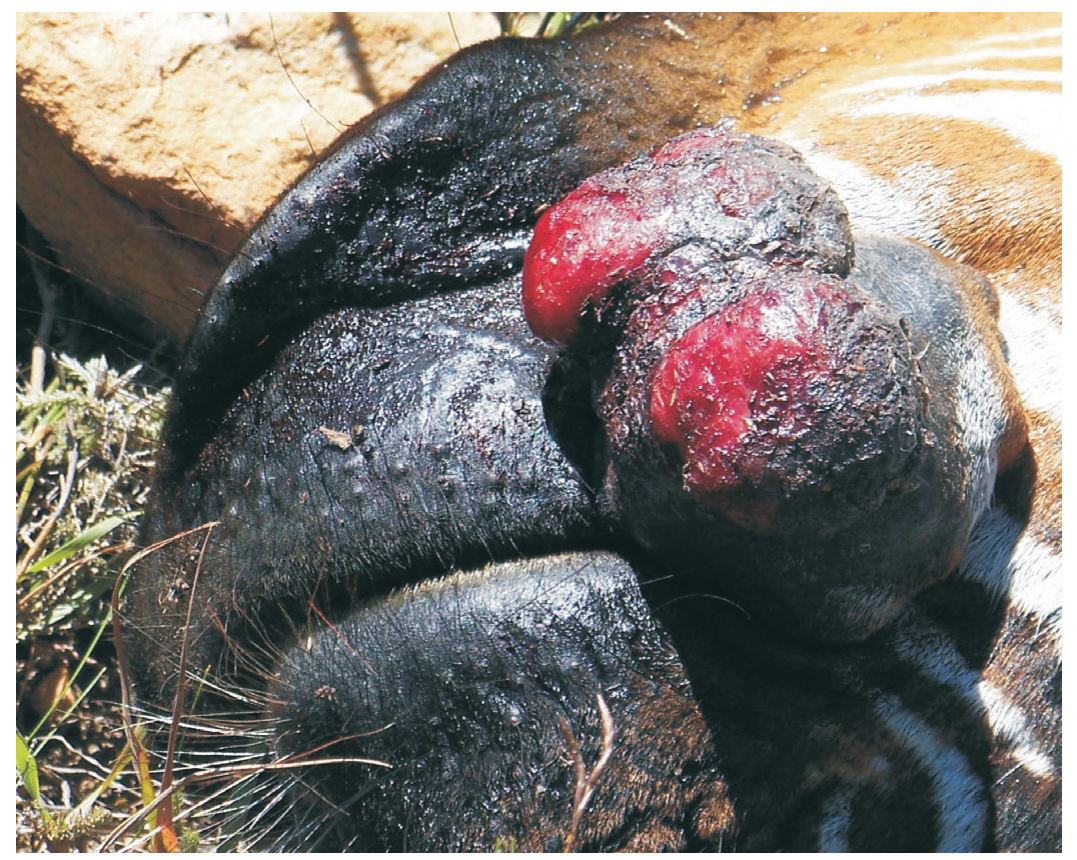

Fig. 1. Sarcoid tumour on the face of a Cape mountain zebra.

Dam Nature Reserve (GDNR), with $53 \%$ of BNP and $22 \%$ of GDNR Cape mountain zebras reported to be visibly diseased (Nel et al. 2006; Marais et al. 2007). A review of the epidemiology, virology and genetics of sarcoid tumours and history of inbreeding in BNP and GDNR populations (Sasidharan 2006) and confirmation of the presence of Bovine papilloma virus (BPV) detected from tumour (van Dyk et al. 2004) and blood (van Dyk et al. 2009) samples taken from affected zebras have added to the comprehensive histopathological and genetic evidence on the involvement of BPV in the pathogenesis of tumours in South African Cape mountain zebras.

Appearance of fibropapillomatous growths have been documented in various species (Schulman et al. 2001; Schulman et al. 2003), extensively studied within the Equidae (Reid et al. 1994; Chambers et al. 2003) and correlated to genetic factors (Marti et al. 1993; Lazary et al. 1994). The emergence of papillomavirus-induced disease is associated with lowered immunity and presence of environmental or genetic cofactors (Campo 2003). Ragland et al. (1966) reported an outbreak of sarcoids in horses (Equus ferus caballus) and noted a familial pattern in the epizootic, with affected animals originating from a highly inbred family. In Equidae, the expression of unknown autosomal, dominant gene/s with incomplete penetration is suspected to contribute to the predisposition of horses to sarcoids and virus activation (Meredith et al. 1986). Specific immune system genes are down-regulated by papillomavirus in the equine final host (Ashrafi et al. 2006; Yuan et al. 2008). Genetic susceptibility to papillomavirus has been documented in rabbits (Favre et al. 1997), humans (Lowy 2001) and other animals (Kidney et al. 2001; Tachezy et al. 2002).

Inbreeding has been correlated to disease susceptibility in cheetahs (Acinonyx jubatus; O’Brien \& Yukhi 1999), California sea lions (Zalophus californianus; Acevedo-Whitehouse et al. 2003) and humans (Rudan et al. 2003). Increased parental similarity has been correlated to higher internal parasite loads in Soay sheep (Ovis aries; Coltman et al. 1999), decreased birth weight, juvenile survival (Coulson et al. 1998) and lowered adult reproductive success in red deer (Cervus elaphus; Slate et al. 2000) and increased mortality in harbour seals (Phoca vitulina; Coltman et al. 1998). Inbreeding also increases mortality from parasitism and extreme climatic variation (Keller et al. 1994; Coltman et al. 1999; Kalinowski et al. 2000).

The tumour-affected zebras in BNP originated from the MZNP population and those in GDNR were from a breeding nucleus of six Cape mountain zebras that were translocated from the Cradock 


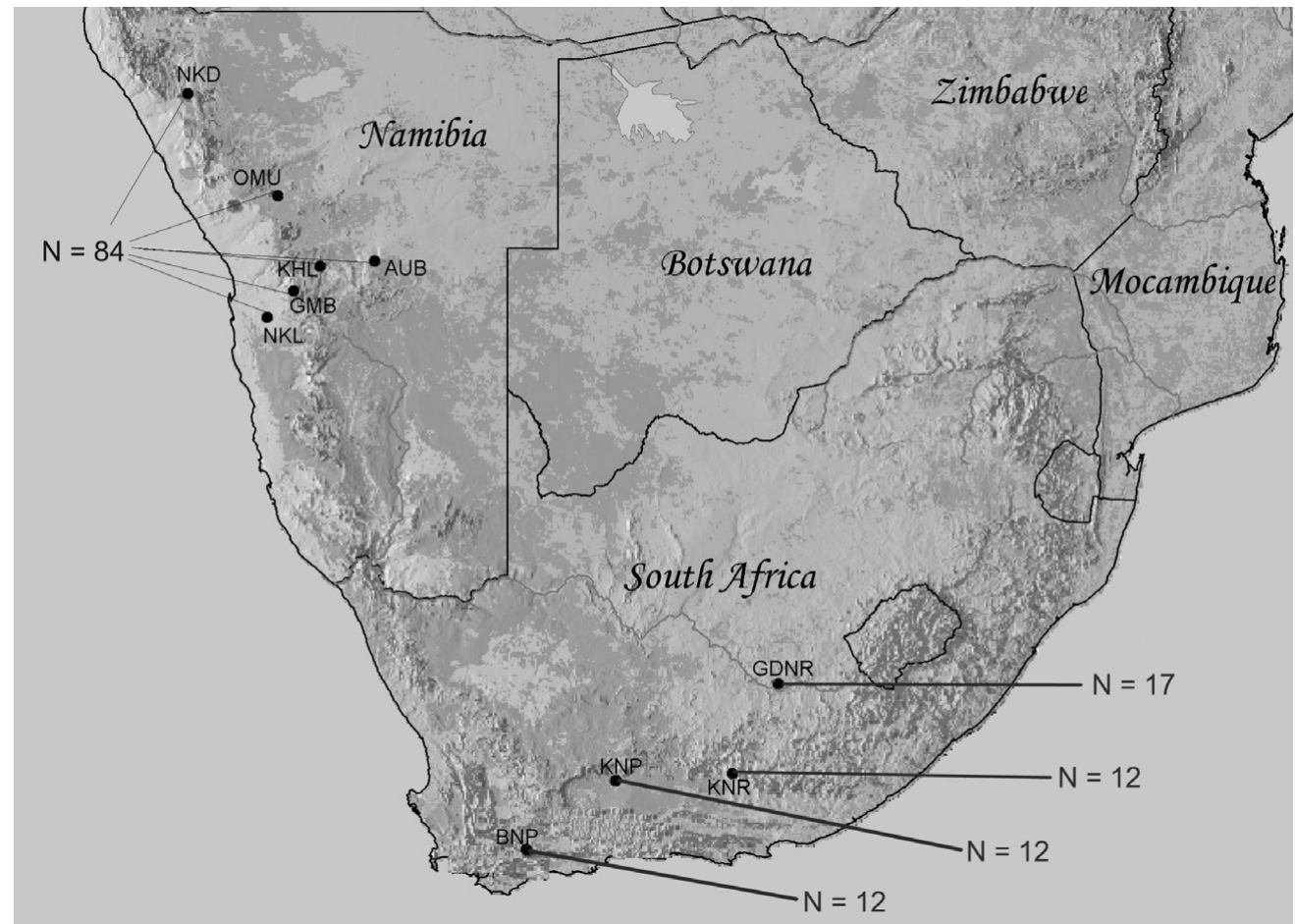

Fig. 2. Map of southern Africa indicating areas from where the samples originated. Hartmann's zebra samples: AUB $=$ Auasberg, GMB = Gamsberg, KHL = Khomas Hochland, NKL = Naukluft, NKD = Northern Kamanjab District and OMU = Omaruru. Cape mountain zebra samples: BNP = Bontebok National Park, GDNR = Gariep Dam Nature Reserve, KNP = Karoo National Park and KNR = Karoo Nature Reserve.

area near MZNP. Additions to these two populations came from the KNP or MZNP. The KNP was itself established in 1978 by introduction of zebras from MZNP. It is among the few seeded populations where a high population growth has been recorded (Novellie et al. 2002). The Karoo Nature Reserve (KNR) was seeded with 20 animals from MZNP in 1981 and has also exhibited a good population growth to reach a total of over 120 animals. Mountain zebras in Namibia did not go through a period of population reduction and demographic bottleneck as did the Cape mountain zebras (Moodley \& Harley 2005), with populations estimated to be between 20000 and 30000 , maintained in state-protected areas, conservancies in communal land, private farmland and other state-owned land (Novellie et al. 2002). The genetic structuring and population genetic parameters within Namibian Hartmann's mountain zebra have been reported earlier (Moodley \& Harley 2005), with two main groups detected.

In general, high inbreeding levels have been correlated to greater disease susceptibility, low survivorship and higher parasitism, decreased birth weight and juvenile survival, and lowered adult reproductive success (Frankham et al. 2002; Allendorf \& Luikart 2007). In this study, samples from four Cape mountain zebra populations, including two non-affected and two tumour-affected populations, were genotyped and compared along with Namibian Hartmann's mountain zebra populations. With a wealth of information correlating genetic susceptibility and inbreeding to the appearance of papillomaviral and specifically BPV-related diseases, this study aimed to compare population genetic parameters between the different mountain zebra populations and investigate if the apparent loss of fitness in the tumouraffected populations is related to lack of genetic diversity.

\section{METHODS}

The mountain zebras from Namibia $(n=84)$ originated from populations in and around Gamsberg, Auasberg, Omaruru, Naukluft, Kamanjab District (north) and Khomas Hochland areas in Namibia (Fig. 2) and were collected as part of another study (Moodley \& Harley 2005). South African Cape 
mountain zebra samples from BNP $(n=12)$, GDNR $(n=17), \operatorname{KNP}(n=12)$ and $\operatorname{KNR}(n=12)$ were collected after immobilization and $10 \mathrm{ml}$ blood was collected from the jugular vein in barcode-labelled EDTA BD Vacutainer ${ }^{\mathrm{TM}}$ tubes. DNA was extracted from blood samples by a standard protocol (Sambrook et al. 1989).

Forward primers for 16 domestic horse microsatellite primers were end-labelled and assigned to three multiplex panels, with the primer concentrations and PCR profiles as previously described (Sasidharan et al. 2003). Electrophoresis on the PCR products was carried out in an ABI PRISM 310 Genetic Analyser (Applied Biosystems, Foster City, CA). Allele assignments were done using the ABI PRISM 310 Collection Software application (version 3.0.0; Applied Biosystems, Foster City, CA) and STRand software (version 2.2.224; Board of Regents, University of California, Davis).

A selection of random samples $(n=10)$ were re-extracted and amplified to confirm typing quality. Amplification and consistency of PCR products were checked using Microsatellite Toolkit (Park 2001). Estimates of the frequency of null alleles were determined by an iterative algorithm based on the observed and expected frequencies of homozygotes implemented in CERVUS 3.0 (Marshall et al. 1998). Observed $\left(H_{\circ}\right)$ and expected mean heterozygosities $\left(\mathrm{H}_{\mathrm{E}}\right)$, polymorphic information content (PIC) and average number of alleles for each microsatellite loci were calculated using CERVUS 3.0.

Internal relatedness (IR), a measure of heterozygosity that uses allele frequencies to weight scores according to the alleles in the genotype (Amos et al. 2001) and homozygosity by loci (HL), a measure that weights the contribution of each locus to the homozygosity value depending on their allelic variability (Aparicio et al. 2006), were used to compare diversity between tumouraffected and non-affected populations. HL weights informative loci more in relation with their allelic variability instead of weighting by allele frequencies and removes the problem with IR where it underestimates heterozygosity of individuals carrying rare alleles (Aparicio et al. 2006; Ortego et al.2007). The significance between populations was tested using a $t$-test.

Hardy-Weinberg equilibrium of genotypes within populations was tested using GENEPOP (Version 3.3) package (Raymond \& Rousset 1995). A Markov chain method was used to calculate exact probabilities, to estimate without bias, the exact
$P$-value (at 1000 dememorization steps, 1000 batches and 10000 iterations per batch). The significance of resulting $P$-values from multiple tests was assessed using sequential Bonferroni correction. Two groupings, the pooled Cape mountain zebra and Hartmann's mountain zebra populations, were analysed for heterozygote deficit or excess and Hardy-Weinberg exact tests were then carried out with similar Markov chain parameters for all tests. Genotype disequilibrium was tested using Markov chain and Fisher's exact procedures by GENEPOP software. The settings for the exact probabilities were 5000 dememorization steps, 1000 batches and 10000 iterations per batch. Within population inbreeding statistic $\left(F_{1 S}\right)$ for each locus were calculated using FSTAT (Version 2.9.3.2) software (Goudet 1995) and permutation tests with sequential Bonferroni procedure determined the significance levels and values were obtained by jackknifing over loci. Overall $F$-statistic values were calculated for the following population groupings: Group A consisting of pooled samples from the two sarcoid affected populations, Group B consisting of tumour-free Cape mountain zebra populations and Group C, the pooled sample of Hartmann's zebras. Wright's Fst $(\theta)$ (Weir \& Cockerham 1984) and $95 \%$ confidence intervals of $\theta$ were calculated by bootstrapping (1000 replicates).

ARLEQUIN (version 3) (Excoffier et al. 2005) was used to estimate exact tests of population differentiation (10 000 Markov chain and 5000 dememorization steps). $P$-values were calculated and compared with the significance level set at 0.05 . A hierarchical $F_{\mathrm{ST}}$ analysis was carried out using analysis of molecular variance (AMOVA), in order to estimate population structure at different levels of the specified hierarchy. Differentiation was analysed between tumour-affected and nonaffected Cape mountain zebra subpopulations. The null hypothesis of no differentiation at the corresponding level was tested at 20000 permutations.

We also studied population structure using Bayesian clustering, a technique better suited for analysing genetic data by detecting subtle signals of linkage and Hardy Weinberg disequilibrium to group individuals into genetically distinct clusters (Corander et al. 2003; Beaumont \& Rannala 2004; Latch et al. 2006; Vaha \& Primmer 2006). The software STRUCTURE (Pritchard et al. 2000) was used, with no assumptions made on prior knowledge of the population structure. Since the Cape 
mountain zebras investigated were originating from a narrow Cradock-derived founder stock, we used a model with correlated allele frequencies (admixture allowed) and no prior population information. A series of 10 independent runs of the Gibbs sampler was done for values of $K$ (representing the number of populations) between 1 and 8, with 1000000 iterations following a burn-in period of 100000 iterations. Estimates of $P(X \mathrm{IK})$ over the different runs were compared and checked for consistency across runs and parameters reaching equilibrium before end of burn-in. To derive the best estimate for $K$, the measure $\Delta K$ (Evanno et al. 2005) was used to avoid bias. The value $\Delta K$ is derived as the second order rate of change of $\ln [\operatorname{Pr}(X \mid K)]$ with respect to $K$, and provides a reliable estimator for the uppermost hierarchical level of structure (Waples \& Gaggiotti 2006). Delta $K$ statistic is useful in cases where the probability value given by STRUCTURE increases roughly asymptotically. The estimate was obtained by the following calculation on a spreadsheet:

$\Delta K=\operatorname{mean}(\mid L(K+1)-2 L(K)+L(K-$

1) | $) / S . D .[L(K)]$,

where

$L=\operatorname{Pr}(X \mid K)$ and S.D. = standard deviation.

\section{RESULTS}

DNA deterioration was noted in samples collected from field specimens originating from KNP and $\mathrm{KNR}$, contributing to the non-amplification, high rate of typing failure and deficit of heterozygotes for five microsatellites. As a result, five microsatellites, (ASB2, HMS42, LEX52, LEX64 and UMO11) were not used for subsequent comparative analysis between Cape mountain zebra populations. LEX33 failed to amplify in all Hartmann's mountain zebras tested, possibly due to primer mutation in the subspecies. LEX3 is sex-linked in the horse (Chowdhary et al. 2003) and although its chromosomal location is yet to be determined in zebras, our data indicates it might be sex-linked in mountain zebras and was subsequently excluded. Hence, nine microsatellites were used for all comparative analyses that included the two populations, KNP and KNR.

In Cape mountain zebra, three microsatellite loci (AHT5, HTG10 and HTB4) indicated rejection of the null hypothesis of random association of alleles (Hardy-Weinberg equilibrium). In Hartmann's mountain zebras, $P$-values indicative of deviation from
Hardy-Weinberg equilibrium after multiple tests were detected for HMS3, HMS6 and HTG4. Taking all possible locus pairs into account across all populations, genotypic disequilibrium calculations indicated significant linkage between two locus pairs, AHT4 and AHT5 $\left(\chi^{2}=33.54\right.$, d.f. $=10$, $P=0.00022)$ and ASB23 and HTG10 $\left(\chi^{2}=34.83\right.$, d.f. $=6, P=0.0000$ ).

Significant heterozygote deficit was observed for two loci, AHT5 and HTG4, among the Cape mountain zebra populations analysed.

The number of alleles detected and expected heterozygosities for all the microsatellites used in this study is listed in Table 1. Sarcoid tumouraffected populations had the lowest mean number of alleles as a group (Fig. 3) and populations (Fig. 4) but were not significantly different when compared with tumour-free Cape mountain zebra populations. However, the differences in means of diversity values, including expected mean heterozygosities $\left(H_{E}\right)$, internal relatedness (IR) and homozygosity by loci (HL) were in the direction expected if higher heterozygosity increases resistance to disease development (Table 2). Expected heterozygosity levels reported from four other Cape mountain zebra populations (Moodley \& Harley 2005) were much lower, varying from 0.28 to 0.38 , possibly reflecting differences in marker selection and methodology. Mean $\mathrm{H}_{E}$ for the Hartmann's mountain zebra subspecies was 0.609 and revealed a three-fold increase in mean alleles per loci compared to Cape mountain zebra. High heterozygosity levels are common amongst feral populations of equids. In donkeys (Equus africanus asinus), the average $\mathrm{H}_{\mathrm{E}}$ varies from 0.623 (Bellone et al. 1998), 0.712 (Jordana et al. 2001) to 0.70 (Ivankovic et al. 2002). Heterozygosity levels ranging from 0.519 to 0.795 were reported for plains zebra populations (Moodley 2002).

Wright's $F_{1 S}$ statistic for each locus was measured and 'within population' inbreeding values for individual populations were obtained using nine microsatellites (Table 3). Genetic substructuring in Cape mountain zebras, when analysed through a pair-wise analysis of different populations, by the 'within population' inbreeding estimate $\left(f=F_{I S}\right)$, indicated an overall deficit of heterozygotes in the affected and non-affected Cape mountain zebra populations (Table 4). The required level of significance was only reached in the Hartmann's mountain zebra. Total inbreeding estimates $\left(F_{\mathrm{IT}}\right)$ for Hartmann's mountain zebras (0.181) indicated a 
Table 1. Alleles detected and expected heterozygosities between Cape mountain zebras and Hartmann's mountain zebras.

\begin{tabular}{|c|c|c|c|c|c|c|}
\hline \multirow[t]{2}{*}{ Microsatellite } & \multicolumn{3}{|c|}{ Cape mountain zebra } & \multicolumn{3}{|c|}{ Hartmann's mountain zebra } \\
\hline & $n$ & Alleles & $\mathrm{H}_{\mathrm{E}}$ & $n$ & Alleles & $\mathrm{H}_{\mathrm{E}}$ \\
\hline AHT4 & 51 & 4 & 0.591 & 84 & 17 & 0.817 \\
\hline AHT5 & 50 & 4 & 0.591 & 84 & 6 & 0.536 \\
\hline ASB2 & 29 & 1 & 0 & 26 & 3 & 0.521 \\
\hline ASB17 & 52 & 3 & 0.536 & 84 & 10 & 0.769 \\
\hline ASB23 & 51 & 4 & 0.427 & 82 & 14 & 0.898 \\
\hline HMS3 & 52 & 2 & 0.503 & 74 & 3 & 0.239 \\
\hline HMS6 & 51 & 2 & 0.239 & 80 & 4 & 0.515 \\
\hline HMS42 & 28 & 2 & 0.07 & 71 & 4 & 0.242 \\
\hline HTG4 & 47 & 3 & 0.55 & 81 & 4 & 0.589 \\
\hline HTG10 & 52 & 3 & 0.633 & 74 & 9 & 0.695 \\
\hline LEX3 & 29 & 2 & 0.508 & 63 & 8 & 0.781 \\
\hline LEX33 & 29 & 2 & 0.407 & 0 & 0 & 0 \\
\hline LEX52 & 28 & 1 & 0 & 69 & 3 & 0.124 \\
\hline LEX64 & 27 & 2 & 0.409 & 66 & 10 & 0.776 \\
\hline UMO11 & 28 & 3 & 0.658 & 71 & 7 & 0.354 \\
\hline VHL20 & 52 & 3 & 0.363 & 83 & 9 & 0.446 \\
\hline
\end{tabular}

relatively outbred population. The hierarchical $F_{\mathrm{ST}}$ analysis carried out using AMOVA revealed a higher level of differentiation between tumour affected and non-affected Cape mountain zebras, than among all the Cape mountain zebra populations and within single populations; 0.2787 vs 0.1202 , and 0.1801 , respectively.

Results from the Bayesian clustering approach

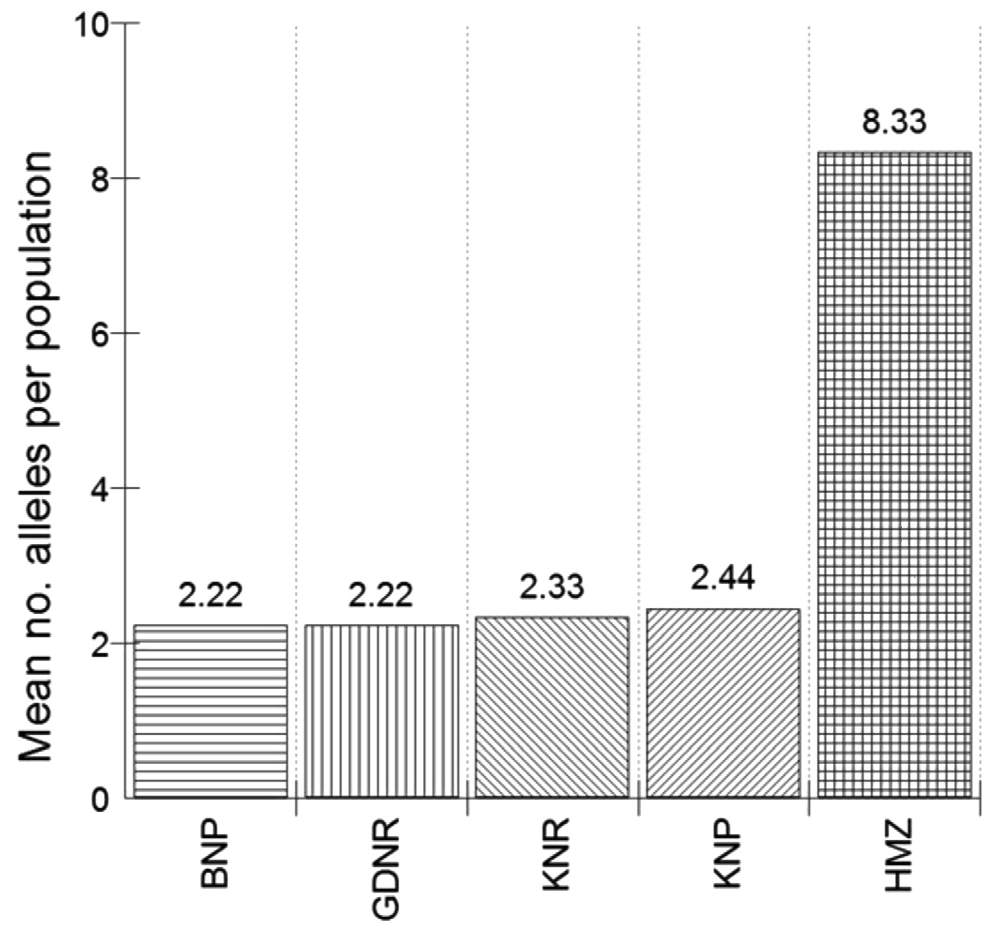

Fig. 3. Mean number of alleles per group. Affected $=\mathrm{BNP}+\operatorname{GDNR}(n=29)$, unaffected $=\mathrm{KNP}+\mathrm{KNR}(n=24)$ and HMZ $(n=84)$. 
Table 2. Differences in diversity levels between tumour-free and tumour-affected populations.

\begin{tabular}{lccccc}
\hline Zebra Populations & $\begin{array}{c}\text { Mean } \mathrm{H}_{\mathrm{E}} \\
(P=0.561)\end{array}$ & $\begin{array}{c}\text { Mean HL } \\
(P=0.084)\end{array}$ & $\begin{array}{c}\text { Mean IR } \\
(P=0.314)\end{array}$ & $\begin{array}{c}\text { Mean alleles } \\
\text { per locus }\end{array}$ & Mean PIC \\
\hline Tumour-free $(n=29)$ & 0.427 & 0.509 & 0.102 & 2.44 & 0.311 \\
Tumour-affected $(n=24)$ & 0.386 & 0.603 & 0.201 & 2.67 & 0.335 \\
\hline
\end{tabular}

$\mathrm{H}_{\mathrm{E}}=$ expected heterozygosity.

$\mathrm{HL}=$ homozygosity by loci (Aparicio et al. 2006).

IR = internal relatedness (Amos et al. 2001).

$\mathrm{PIC}=$ polymorphic information content.

mirrored AMOVA results in giving a clear differentiation between the historically distinct Hartmann's and Cape mountain zebra populations, with all Hartmann's mountain zebras clustering with high degree of probability (>95\%) to one putative population (data not shown). Analysis of the Cape mountain zebra populations alone revealed evidence for four populations $(K=4)$ obtainable from $(\operatorname{Pr}(X \mid K)$ (Fig. 5). and two populations from the $(\Delta K)$ method used (Fig. 6). When Hartmann's mountain zebra was included in the clustering, distinction between the two tumour-free Cape mountain zebra populations (KNP and KNR) became less clear (data not shown). Four groups were distinguishable with STRUCTURE in propor- tions similar to actual populations of origin (Fig. 7). Delta $K$ method was consistent in revealing two clusters (Fig. 8).

\section{DISCUSSION}

Attempting to demonstrate inbreeding depression in feral populations can be difficult (Slate et al. 2000). However, inbreeding and its effects in populations have been well documented (Ralls et al. 1988; Lacy et al. 1993; Lacy 1997; Hedrick \& Kalinowski 2000; Ives \& Whitlock 2002; Charlesworth 2003) and correlations with disease susceptibility reported widely (Coltman et al. 1999; Acevedo-Whitehouse et al. 2003; Altizer et al. 2003). Positive correlations have been reported

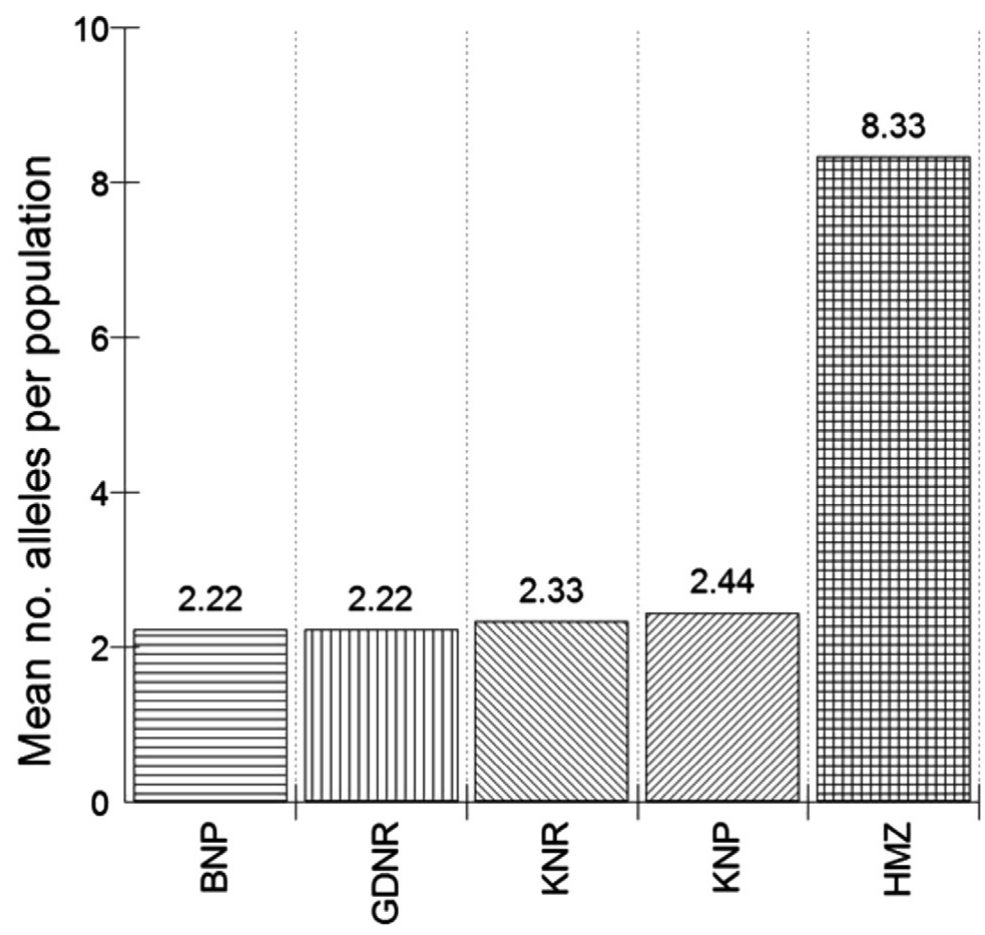

Fig. 4. Mean number of alleles per population (BNP = Bontebok National Park, GDNR = Gariep Dam Nature Reserve, KNP $=$ Karoo National Park and KNR = Karoo Nature Reserve). 
Table 3. Within population inbreeding values (Wright's $F_{I S}$ statistic) for mountain zebra populations (BNP = Bontebok National Park; GDNR = Gariep Dam Nature Reserve; KNP = Karoo National Park; KNR = Karoo Nature Reserve; $\mathrm{HMZ}=$ Hartmann's mountain zebra).

\begin{tabular}{|c|c|c|c|c|c|}
\hline \multirow[t]{2}{*}{ Locus } & \multicolumn{5}{|c|}{$F_{I S}$ values of the different populations } \\
\hline & BNP & GDNR & KNP & KNR & $\mathrm{HMZ}$ \\
\hline AHT4 & $0.028^{*}$ & -0.012 & $0.416^{\star \star}$ & -0.252 & $0.068^{\star * *}$ \\
\hline AHT5 & -0.048 & -0.032 & $0.416^{\star \star}$ & $0.407^{*}$ & $0.013^{* * *}$ \\
\hline ASB17 & -0.203 & -0.286 & -0.128 & -0.268 & $0.182^{\star * *}$ \\
\hline ASB23 & -0.048 & -0.151 & $0.185^{\star}$ & -0.08 & $0.063^{\star \star *}$ \\
\hline HMS3 & -0.375 & -0.103 & $0.681^{* *}$ & -0.176 & $0.549^{* * *}$ \\
\hline HMS6 & $0.436^{* *}$ & NA & -0.048 & -0.5 & $0.377^{* * *}$ \\
\hline HTG10 & -0.132 & -0.043 & -1 & -1 & $0.106^{\star \star *}$ \\
\hline VHL20 & -0.197 & -0.103 & -0.294 & NA & NA \\
\hline HTG4 & $0.29^{*}$ & NA & -0.077 & -0.125 & $0.478^{* * *}$ \\
\hline All & -0.044 & -0.106 & $0.024^{\star *}$ & -0.287 & $0.171^{* * *}$ \\
\hline
\end{tabular}

$\mathrm{F}_{\mathrm{IS}}$ : The 'within population' inbreeding estimate $\left(f=\mathrm{F}_{\mathrm{IS}}\right)$ or value of deficit of heterozygotes.

${ }^{*} P<0.01,{ }^{* *} P<0.001,{ }^{* *} P<0.0001$

between heterozygosity and fitness parameters such as longevity, growth rates, fecundity, metabolic efficiency and overall developmental stability (Mitton 1978; Mitton \& Grant 1984) and increased infant mortality, decreased litter size, infertility and susceptibility to disease (Wright 1978; Ralls et al. 1988; Falconer \& Mackay 1996). Comparing levels of average heterozygosity, mean number of alleles per loci, effective number of alleles, mean range of microsatellite repeats and microsatellite variance estimates between a population of interest and its free-ranging counterpart are useful to determine loss of genetic variation. The appearance of sarcoid tumours in equids has been correlated with specific genetic haplotypes (Chambers et al. 2003) with the involvement of BPV in the formation of sarcoid tumour in equids proven (Lohr et al. 2005; Brandt et al. 2008) and correlated with down-regulation of immune system genes (Ashrafi et al. 2006; Yuan et al. 2008). The only previous epizootic of sarcoid tumour reported was in horses, with four of the five affected individuals being members of a highly inbred herd (Ragland et al. 1966).

This study revealed that among the four Cape mountain zebra populations investigated, the mean number of alleles, expected heterozygosity values, allele richness and gene diversities were lowest and mean $\mathrm{HL}$ and IR values were highest in the diseased populations (BNP and GDNR). Although none of the parameters were significant at $P=0.05$, the means were in the direction expected if increasing levels of multilocus heterozygosity would be expected to increase disease resistance. Neutral genetic markers that detect levels of shared genes in a population, function on the theory that variations at these neutral loci reflect genome-wide heterozygosity at unlinked genes [general effect hypothesis] (Hansson \& Westerberg 2002).

Tests for heterozygote deficit indicated that there is low allele diversity for all microsatellites analysed within Cape mountain zebra populations and contributed to the observed deviations from Hardy-Weinberg equilibrium. The locus pairs (AHT4-AHT5 and ASB23-HTG10) were found to exhibit significant linkage among all the possible locus pairs at a global level. Of these alleles, AHT4 also showed a significant heterozygote deficit in all Cape mountain zebra populations. Removing these loci for purposes of calculating inbreeding levels, however, did not change the values by any significant manner. Recent and sustained co-sanguinity is suspected to be the biggest contributor for the lack of diversity and male stallions maintaining multigenerational harems might have contributed to extreme drift in Cape mountain zebra populations. The fixation of private alleles has demonstrably contributed to the detectable differentiation between different Cape mountain zebra populations.

The results from AMOVA reflected extreme heterozygote deficiency among tumour-affected populations, possibly due to either a Wahlund effect caused by sampling functionally independent social reproductive harems that has confounded the interpretation of Wright's $F_{I S}$ (Storz et al. 2001). 
Table 4. Genetic substructuring in Cape mountain zebras analysed through a pair-wise analysis of different populations, by the 'within population' inbreeding estimate $\left(f=F_{I S}\right)$.

\begin{tabular}{|c|c|c|c|}
\hline Population^ & $F_{I S}=f$ & $F_{I T}=F$ & $F_{S T}=\theta$ \\
\hline BNP-GDNR (tumour-affected Cape mountain zebra) & $-0.077(0.050)$ & $0.096(0.062)$ & $0.161(0.048)$ \\
\hline KNP-KNR (unaffected Cape mountain zebra) & $-0.115(0.164)$ & $-0.024(0.170)$ & $0.082(0.038)$ \\
\hline Hartmann's zebra population & $0.168(0.056)^{\star * *}$ & $0.181(0.053)$ & - \\
\hline
\end{tabular}

$\wedge$ From nine informative loci.

$f$ : within population inbreeding estimate; $F$ : total inbreeding estimate; $\theta$ : measure of population differentiation.

Standard deviation in brackets estimated from jackknife over loci.

${ }^{* \star \star} P<0.001$, from permutation tests in FSTAT (Version 2.9.3.2).

Bayesian clustering did enable differentiation between Hartmann's and Cape mountain zebra populations, with the majority of Hartmann's mountain zebras clustering with high degree of probability $(>95 \%)$ to one putative population. Differentiation between the Cape mountain zebra populations using STRUCTURE alone revealed evidence for four populations whereas only two populations were derived using Evanno's $(\Delta K)$ method used. Distinction between the two tumourfree Cape mountain zebra populations (KNP and KNR) was lost when Hartmann's mountain zebra was added and overall four groups were distinguishable, Gariep, Bontebok, KNP-KNR combined and the Hartmann's mountain zebras. The Delta $K$ statistic again identified the number of clusters as two, reflecting the true genetic differentiation between Hartmann's mountain zebras and
Cape mountain zebras. The genetic distinction between KNP and KNR needs to be further investigated with more markers and samples included in future studies.

The presence of a reproductive substructure may well have accelerated the genetic drift, possibly driven by stallions maintaining multigenerational harems (Penzhorn 1979). Both the tumouraffected populations have been recorded have extreme founder effects, with few stallions siring the majority of the foals and the other males forming bachelor herds and not contributing to the gene pool (Marais et al. 2003; Marais 2006; Nel 2007). The relatively successful establishment and thriving of the KNP and KNR zebras (Novellie et al. 2002), has in all probability, reduced founder effects in these populations. The significant population differentiation between two tumour-

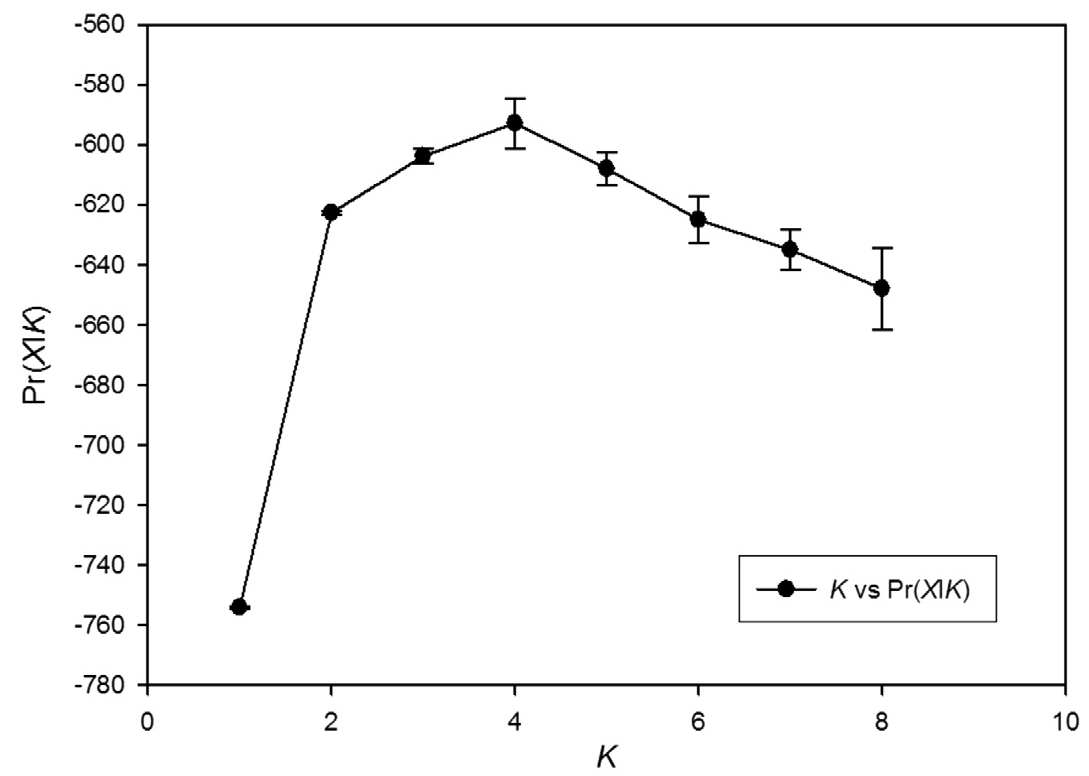

Fig. 5. Dataset of Cape mountain zebra populations: $K=4$ clusters detected from posterior probability of the data given a particular value of $K(\operatorname{Pr}(X \mid K))$ from STRUCTURE. 


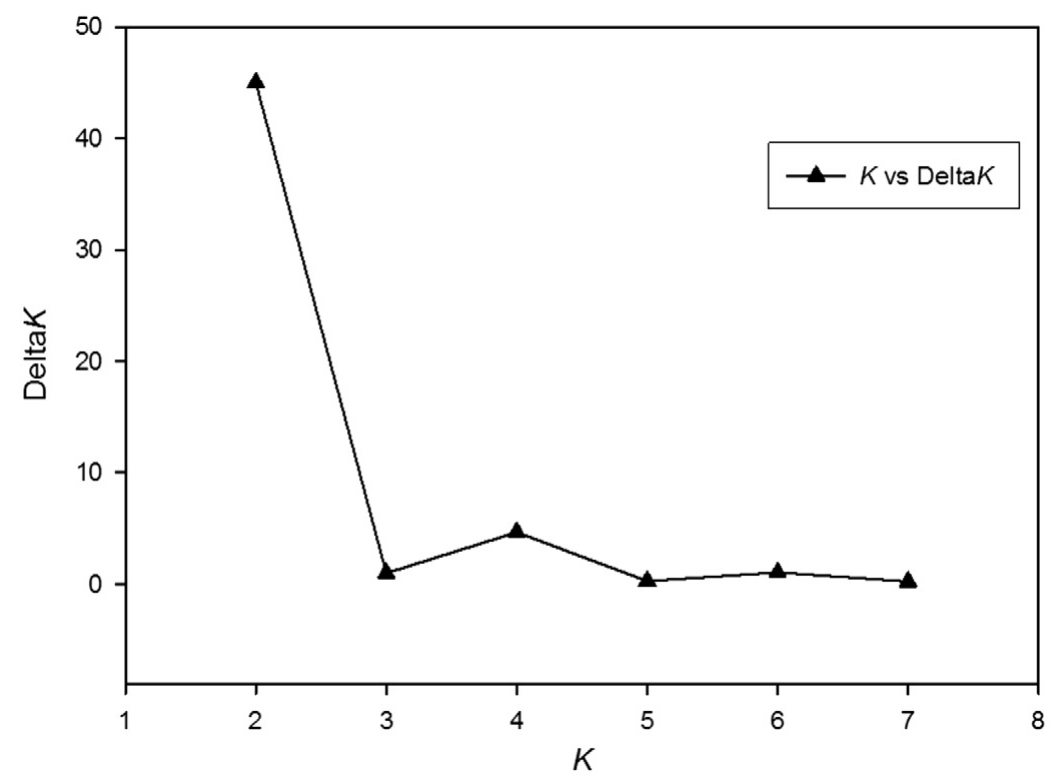

Fig. 6. Dataset of Cape mountain zebra populations: $K=2$ clusters detected from second order rate of change for $K(\Delta K)$.

affected populations and non-affected might be a consequence of the combined action of extreme founder effects and persistence of private alleles.

This investigation revealed that the two diseased populations have the least genetic variation of the four Cape mountain zebra populations and significant structure exists between subpopulations. It could thus be demonstrated that Cape mountain zebras, after surviving a historically documented genetic bottleneck (Bigalke 1952), have, when compared to free-ranging Hartmann's mountain zebras in Namibia, very little genetic variation left. The tumour-free populations and other Cape mountain zebra populations appear to be lacking

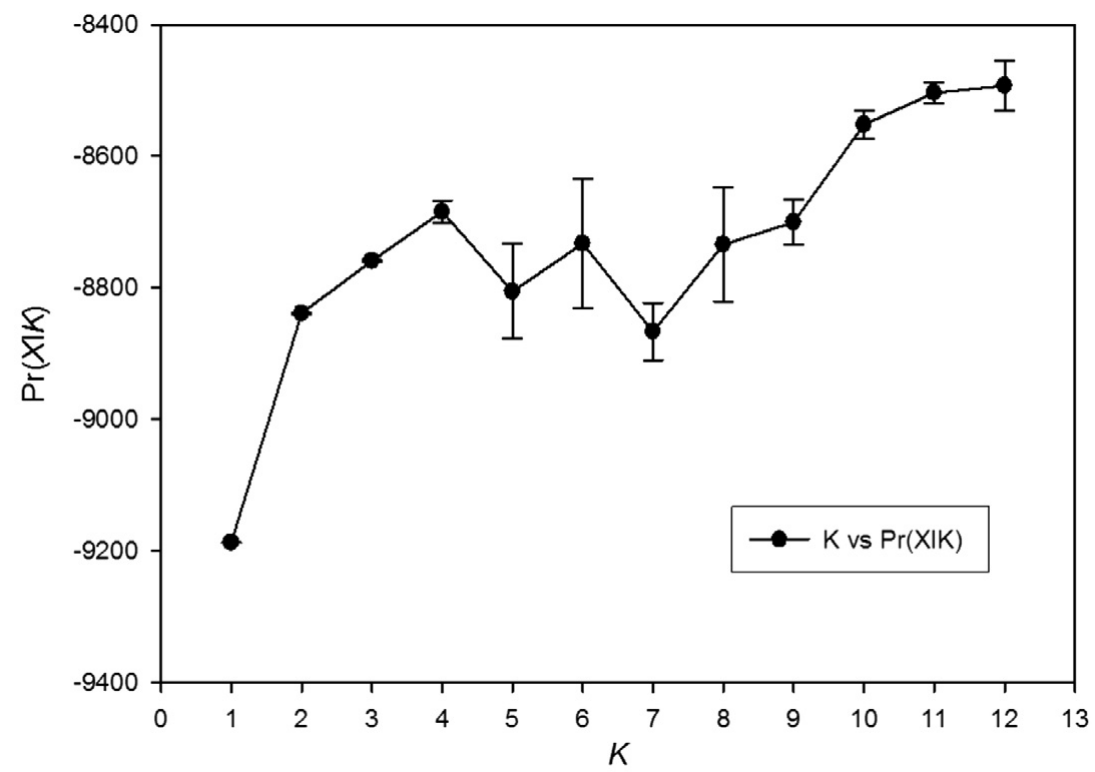

Fig. 7. Dataset of Cape mountain zebra and $\mathrm{HMZ}$ populations: $K=4$ clusters detected from posterior probability of the data given a particular value of $K(\operatorname{Pr}(X \mid K))$ from STRUCTURE. 


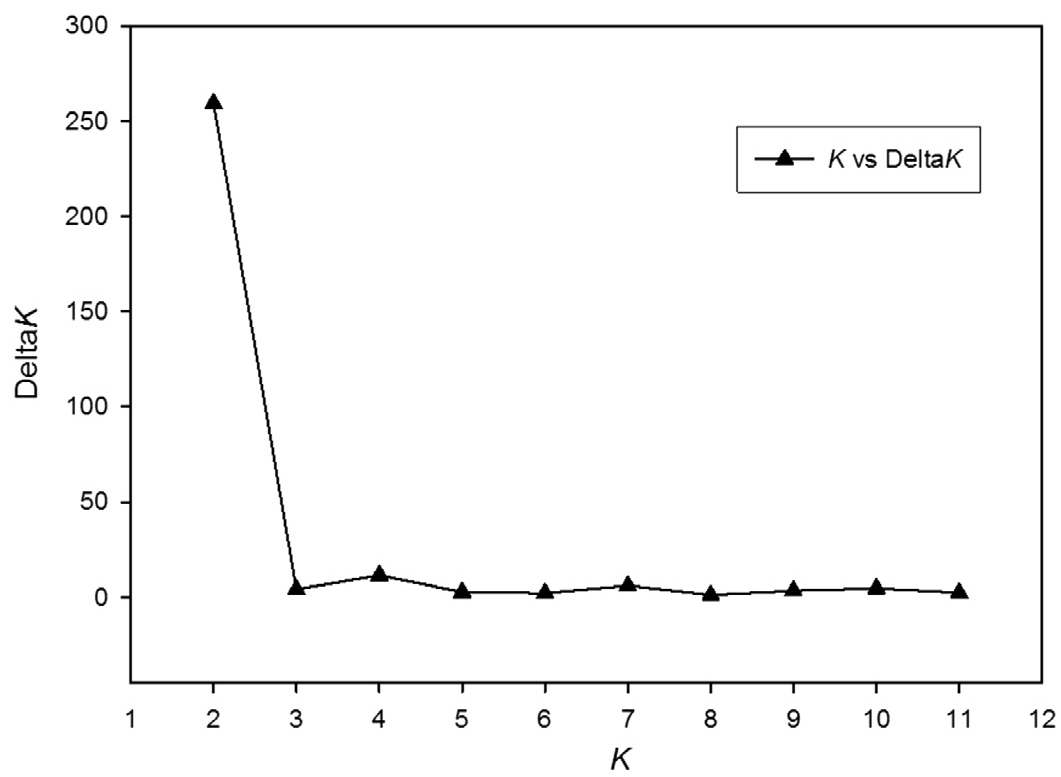

Fig. 8. Dataset of Cape mountain zebra and HMZ populations: $K=2$ clusters detected from second order rate of change for $K(\Delta K)$.

in diversity on a similar scale (Moodley \& Harley 2005) and could be at risk for developing tumours. Development of sarcoid tumour in equids is triggered by a virus-induced cascade of transcriptional changes leading to immunological failure, lack of apoptosis, increased cell motility and invasion, events that potentially involve over 50 genes (Yuan et al. 2008). The multigenic nature of tumour formation increases the possibility that neutral loci are in linkage with genes influencing fibroblast proliferation and tumour development (local effect). Even though this study did not reveal any conclusive evidence for local effect, the direction of variables were in the direction of an expected correlation between multilocus heterozygosity (including $\mathrm{HL}$ and IR) measured at neutral markers and the heterozygosity of genes influencing fibroblast proliferation under identity disequilibrium (general effect). In isolated Cape mountain zebra populations such as the tumour-affected ones, genetic drift and fixation of alleles might be a common complication, where conditions are not conducive for natural inbreeding-avoidance behaviours and where the inherent social behaviour of Cape mountain zebras accelerates the process of substructuring by maintaining multigenerational harems. Stripe-pattern recognition mechanisms and other natural adaptations are possibly less functional under intensively managed and artificially fenced-in conditions (Penzhorn \& Novellie
1991). Disrupting harems by removing older stallions and translocating family units between isolated Cape mountain zebra populations is a viable strategy to rapidly increase diversity levels. The tumour-affected populations also offer a unique opportunity to use population-wide gene expression profiling as a screening tool to identify candidate genes implicated in this disease.

\section{ACKNOWLEDGEMENTS}

The Faculty of Veterinary Science of University of Pretoria, Equine Research Center and the Veterinary Wildlife Unit provided funding for the project. The Novartis Animal Health South Africa, in conjunction with the South African Veterinary Foundation is acknowledged for funding laboratory costs. This study was made possible by a studentship from the Equine Research Centre.

\section{REFERENCES}

ACEVEDO-WHITEHOUSE, K., GULLAND, F., GREIG, D. \& AMOS, W. 2003. Inbreeding: disease susceptibility in California sea lions. Nature 422: 35-35.

ALLENDORF, F.W. \& LUIKART, G. 2007. Conservation and the genetics of populations. Blackwell, Oxford.

ALTIZER, S., HARVELL, D. \& FRIEDLE, E. 2003. Rapid evolutionary dynamics and disease threats to biodiversity. Trends Ecol. Evol. 18: 589-596.

AMOS, W., WILMER, J.W., FULLARD, K., BURG, T.M., CROXALL, J.P., BLOCH, D. \& COULSON, T. 2001. The influence of parental relatedness on reproductive success. Proc. R. Soc. B 268: 2021-2027. 
APARICIO, J.M., ORTEGO, J. \& CORDERO, P.J. 2006. What should we weigh to estimate heterozygosity, alleles or loci? Mol. Ecol. 15: 4659-4665.

ASHRAFI, G.H., BROWN, D.R., FIFE, K.H. \& CAMPO, M.S. 2006. Down-regulation of MHC class I is a property common to papillomavirus E5 proteins. Virus Res. 120: 208-211.

BEAUMONT, M.A. \& RANNALA, B. 2004. The Bayesian revolution in genetics. Nat. Rev. Genet. 5: 251-261.

BELLONE, R.R., COTHRAN, E.G. \& KETCHUM, M.S. 1998. Genetic variation in the rare donkey breed, Baudet du Poitou. Anim. Genet. 29: 17-17.

BIGALKE, R. 1952. Early history of the Cape mountain zebra (Equus zebra zebra, Linn.). Afr. Wildl. 6: 143-153.

BRANDT, S., HARALAMBUS, R., SCHOSTER, A., KIRNBAUER, R. \& STANEK, C. 2008. Peripheral blood mononuclear cells represent a reservoir of bovine papillomavirus DNA in sarcoid-affected equines. J. Gen. Virol. 89: 1390-1395.

CAMPO, M.S. 2003. Papillomavirus and disease in humans and animals. Vet. Comp. Oncol. 1: 3-14.

CHAMBERS, G., ELLSMORE, V.A., O'BRIEN, P.M., REID, S.W., LOVE, S., CAMPO, M.S. \& NASIR, L. 2003. Association of bovine papillomavirus with the equine sarcoid. J. Gen. Virol. 84: 1055-1062.

CHARLESWORTH, D. 2003. Effects of inbreeding on the genetic diversity of populations. Philos. Trans. R. Soc. Lond. B Biol. Sci. 358: 1051-1070.

CHOWDHARY, B.P., RAUDSEPP, T., KATA, S.R., GOH, G., MILLON, L.V., ALLAN, V., PIUMI, F., GUERIN, G., SWINBURNE, J., BINNS, M., LEAR, T.L., MICKELSON, J., MURRAY, J., ANTCZAK, D.F., WOMACK, J.E. \& SKOW, L.C. 2003. The firstgeneration whole-genome radiation hybrid map in the horse identifies conserved segments in human and mouse genomes. Genome Res. 13: 742-751.

COLTMAN, D.W., BOWEN, W.D. \& WRIGHT, J.M. 1998. Birth weight and neonatal survival of harbour seal pups are positively correlated with genetic variation measured by microsatellites. P. Roy. Soc. Lond. B. 265: 803-809.

COLTMAN, D.W., PILKINGTON, J.G., SMITH, J.A. \& PEMBERTON, J.M. 1999. Parasite-mediated selection against inbred Soay sheep in a free-living, island population. Evolution 53: 1259-1267.

CORANDER, J., WALDMANN, P. \& SILLANPAA, M.J. 2003. Bayesian analysis of genetic differentiation between populations. Genetics 163: 367-374.

COULSON, T.N., PEMBERTON, J.M., ALBON, S.D., BEAUMONT, M., MARSHALL, T.C., SLATE, J., GUINNESS, F.E. \& CLUTTON-BROCK, T.H. 1998. Microsatellites reveal heterosis in red deer. $P$. Roy. Soc. Lond. B. 265: 489-495.

EVANNO, G., REGNAUT, S. \& GOUDET, J. 2005. Detecting the number of clusters of individuals using the software structure: a simulation study. Mol. Ecol. 14: 2611-2620.

EXCOFFIER, L., LAVAL, G. \& SCHNEIDER, S. 2005. Arlequin (version 3.0): An integrated software package for population genetics data analysis. Evol. Bioinform. Online 1: 47-50.
FALCONER, D.S. \& MACKAY, T.F.C. 1996. Introduction to quantitative genetics. Longman Group Limited, Harlow.

FAVRE, M., RAMOZ, N. \& ORTH, G. 1997. Human papillomaviruses: general features. Clin. Dermatol. 15: 181-198.

FRANKHAM, R., BALLOU, J.D. \& BRISCOE, D.A. 2002. Introduction to conservation genetics. Cambridge University Press, Cambridge.

FRIEDMAN, Y. \& DALY, B. 2004. Red data book of the mammals of south africa: a conservation assessment. Conservation Breeding Specialist Group (SSC/ IUCN). Endangered Wildlife Trust. Johannesburg.

GOUDET, J. 1995. FSTAT, Version 1.2: a computer program to calculate F-statistics. J. Hered. 86: 485-486.

HANSSON, B. \& WESTERBERG, L. 2002. On the correlation between heterozygosity and fitness in natural populations. Mol. Ecol. 11: 2467-2474.

HEDRICK, P.W. \& KALINOWSKI, S.T. 2000. Inbreeding depression in conservation biology. Annu. Rev. Ecol. Syst. 31: 139-162.

IVANKOVIC, A., KAVAR, T., CAPUT, P., MIOC, B., PAVIC, V. \& DOVC, P. 2002. Genetic diversity of three donkey populations in the Croatian coastal region. Anim. Genet. 33: 169-177.

IVES, A.R. \& WHITLOCK, M.C. 2002. Ecology. Inbreeding and metapopulations. Science 295: 454455.

JORDANA, J., FOLCH, P. \& ARANGUREN, J.A. 2001. Microsatellite analysis of genetic diversity in the Catalonian donkey breed. J. Anim. Breed. Genet. 118: 57-63.

KALINOWSKI, S.T., HEDRICK, P.W. \& MILLER, P.S. 2000. Inbreeding depression in the Speke's gazelle captive breeding program. Conserv. Biol. 14: 13751384.

KELLER, L.F., ARCESE, P., SMITH, J.N., HOCHACHKA, W.M. \& STEARNS, S.C. 1994. Selection against inbred song sparrows during a natural population bottleneck. Nature 372: 356-357.

KIDNEY, B.A., HAINES, D.M., ELLIS, J.A., BURNHAM, M.L., TEIFKE, J.P., CZERWINSKI, G. \& JACKSON, M.L. 2001. Evaluation of formalin-fixed paraffinembedded tissues from vaccine site-associated sarcomas of cats for papillomavirus DNA and antigen. Am. J. Vet. Res. 62: 833-839.

LACY, R.C. 1997. Importance of genetic variation to the viability of mammalian populations. J. Mammal. 78: 320-335.

LACY, R.C., ANN, P. \& MARK, W. 1993. Inbreeding and outbreeding in captive populations of wild animal species. In: N.W. Thornhill (Ed.), The natural history of inbreeding and outbreeding: theoretical and empirical perspectives (pp. 352-374). University of Chicago Press, Chicago.

LATCH, E., DHARMARAJAN, G., GLAUBITZ, J. \& RHODES, O. 2006. Relative performance of Bayesian clustering software for inferring population substructure and individual assignment at low levels of population differentiation. Conserv. Genet. 7: 295302.

LAZARY, S., MARTI, E., SZALAI, G., GAILLARD, C. \& GERBER, H. 1994. Studies on the frequency and 
associations of equine leucocyte antigens in sarcoid and summer dermatitis. Anim. Genet. 25: 75-80.

LOHR, C.V., JUAN-SALLES, C., ROSAS-ROSAS, A., GARCIA, A.P., GARNER, M.M., TEIFKE, J.P. \& PARÁS GARCÍA, A. 2005. Sarcoids in captive zebras (Equus burchellii): association with bovine papillomavirus type 1 infection. J.Zoo Wildl. Med.36: 74-81.

LOWY, D.R. \& HOWLEY, P.M. 2001. Papillomaviruses. In: D.M. Knipe \& P.M. Howley (Eds), Fields virology (pp. 2231-2264). Lippincott Williams \& Wilkins, Philadelphia.

MARAIS, H.J., NEL, P., BERTSCHINGER, H.J., SCHOEMAN, J.P. \& ZIMMERMAN, D. 2007. Prevalence and body distribution of sarcoids in South African Cape mountain zebra (Equus zebra zebra). J. S. Afr. Vet. Assoc. 78: 145-148.

MARAIS, J. 2006. A study of sarcoid tumours in Cape Mountain Zebra (Equus zebra zebra). M.Sc. thesis, University of Pretoria, Pretoria.

MARAIS, J., NEL, P., SASIDHARAN, S.P., VAN DYK, E., NEL, A., HARPER, C. \& GUTHRIE, A. 2003. Sarcoids in inbred zebra populations. Published by 5 th International Equine Gene Mapping Workshop, Kruger National Park, Skukuza.

MARSHALL, T.C., SLATE, J., KRUUK, L.E.B. \& PEMBERTON, J.M. 1998. Statistical confidence for likelihood-based paternity inference in natural populations. Mol. Ecol. 7: 639-655.

MARTI, E., LAZARY, S., ANTCZAK, D.F. \& GERBER, H. 1993. Report of the first international workshop on equine sarcoid. Equine Vet. J. 25: 397-407.

MEREDITH, D., ELSER, A.H., WOLF, B., SOMA, L.R., DONAWICK, W.J. \& LAZARY, S. 1986. Equine leukocyte antigens: Relationships with sarcoid tumors and laminitis in two pure breeds. Immunogenetics 23: 221-226.

MITTON, J.B. 1978. Relationship between heterozygosity for enzyme loci and variation of morphological characters in natural populations. Nature 273: 661-662.

MITTON, J.B. \& GRANT, M.C. 1984. Associations among protein heterozygosity, growth rate, and developmental homeostasis. Annu. Rev. Ecol. Syst. 15: 479-499.

MOODLEY, Y. 2002. Population structuring in southern African zebras. Ph.D. thesis, University of Cape Town, Cape Town.

MOODLEY, Y. \& HARLEY, E.H. 2005. Population structuring in mountain zebras (Equus zebra): the molecular consequences of divergent demographic histories. Conserv. Genet. 6: 953-968.

NEL, P.J. 2007. An outbreak of equine sarcoid in a population of Cape mountain zebra (Equus zebra zebra) a retrospective study. M.Sc. thesis, University of Pretoria, Pretoria.

NEL, P.J., BERTSCHINGER, H., WILLIAMS, J. \& THOMPSON, P.N. 2006. Descriptive study of an outbreak of equine sarcoid in a population of Cape mountain zebra (Equus zebra zebra) in the Gariep Nature Reserve. J. S. Afr. Vet. Assoc. 77: 184-190.

NOVELLIE, P.A., MILLAR, P.S. \& LLOYD, P.H. 1996. The use of VORTEX simulation models in a long-term programme of re-introduction of an endangered large mammal, the Cape mountain zebra (Equus zebra zebra). Acta Oecol. 17: 657-671.
NOVELLIE, P., LINDEQUE, M., LINDEQUE, P., LLOYD, P. \& KOEN, J. 2002. Status and Action Plan for the Mountain Zebra (Equus zebra). In: P.D. Moehlman (Ed.), Equids: zebras, asses, and horses: status survey and conservation action plan. IUCN/SCC Equid Specialist Group, IUCN, Gland.

O'BRIEN, S.J. \& YUHKI, N. 1999. Comparative genome organization of the major histocompatibility complex: lessons from the Felidae. Immunol. Rev. 167: 133144.

ORTEGO, J., CALABUIG, G., CORDERO, P.J. \& APARICIO, J.M. 2007. Egg production and individual genetic diversity in lesser kestrels. Mol. Ecol. 16: 2383-2392.

PARK, S.D.E. 2001. Trypanotolerance in West African cattle and the population genetic effects of selection. Ph.D. thesis, University of Dublin, Dublin.

PENZHORN, B.L. 1979. Social organisation of the Cape mountain zebra (Equus z. zebra) in the Mountain Zebra National Park. Koedoe 22: 115-156.

PENZHORN, B.L. 1988. Equus zebra. Mammalian Species 314: 1-7.

PENZHORN, B.L. \& NOVELLIE, P.A. 1991. Some behavioural traits of Cape mountain zebras (Equus zebra zebra) and their implications for the management of a small conservation area. Appl. Anim. Behav. Sci. 29: 293-299.

PENZHORN, B.L. \& NOVELLIE, P.A. 1993. Management implications of Cape mountain zebra (Equus zebra zebra) behaviour. In: B.L. Penzhorn (Ed.), Proceedings of an international symposium on capture, care and management of threatened mammals (1993 Kruger National Park, South Africa) (pp. 12-16). Wildlife Group, South African Veterinary Association in collaboration with the World Association of Wildlife Veterinarians, Onderstepoort

PRITCHARD, J.K., STEPHENS, M. \& DONNELLY, P. 2000. Inference of population structure using multilocus genotype data. Genetics 155: 945-959.

RAGLAND, W.L., KEOWN, G.H.\& GORHAM, J.R. 1966 An epizootic of equine sarcoid. Nature 210: 1399.

RALLS, K., JONATHAN, D.B. \& ALAN, T. 1988. Estimates of lethal equivalents and the cost of inbreeding in mammals. Conserv. Biol. 2: 185-193.

RAYMOND, M. \& ROUSSET, F. 1995. GENEPOP (version 1.2): population genetics software for exact tests and ecumenicism. J. Hered. 86: 248-249.

REID, S.W., GETTINBY, G., FOWLER, J.N. \& IKIN, P. 1994. Epidemiological observations on sarcoids in a population of donkeys (Equus asinus). Vet. Rec. 134 207-211.

RUDAN, I., RUDAN, D., CAMPBELL, H., CAROTHERS A., WRIGHT, A., SMOLEJ-NARANCIC, N., JANICIJEVIC, B., JIN, L., CHAKRABORTY, R., DEKA, R. \& RUDAN, P. 2003. Inbreeding and risk of late onset complex disease. J. Med. Genet. 40: 925-932.

SAMBROOK, J., FRITSCH, E.F. \& MANIATIS, T. 1989. Molecular cloning: a laboratory manual. Cold Spring Harbor Laboratory Press, New York.

SASIDHARAN, S.P. 2004. Comparative genetics of selected southern african mountain zebra (Equus zebra zebra and Equus zebra hartmannae) populations. M.Sc. thesis, University of Pretoria, Pretoria.

SASIDHARAN, S.P. 2006. Sarcoid tumours in Cape 
mountain zebra (Equus zebra zebra) populations in South Africa: a review of associated epidemiology, virology and genetics: review article. T. Roy. Soc. S. Afr. 61: 11-18.

SASIDHARAN, S.P., NEL, A., HARPER, C., GUTHRIE, A., BERTSCHINGER, H.J., MOODLEY, Y. \& HARLEY, E. 2003. Applying horse genetic markers to endangered Cape mountain zebra (Equus zebra zebra) populations affected with sarcoid tumour. Faculty Day Proceedings, Faculty of Veterinary Science, University of Pretoria, Onderstepoort, Pretoria.

SCHULMAN, F.Y., KRAFFT, A.E. \& JANCZEWSKI, T. 2001. Feline cutaneous fibropapillomas: clinicopathologic findings and association with papillomavirus infection. Vet. Pathol. 38: 291-296.

SCHULMAN, F.Y., KRAFFT, A.E., JANCZEWSKI, T., REUPERT, R., JACKSON, K. \& GARNER, M.M. 2003. Camelid mucoutaneous fibropapillomas: clinicopathologic findings and association with papillomavirus. Vet. Pathol. 40: 103-107.

SLATE, J., KRUUK, L.E.B., MARSHALL, T.C., PEMBERTON, J.M. \& CLUTTON-BROCK, T.H. 2000. Inbreeding depression influences lifetime breeding success in a wild population of red deer (Cervus elaphus). P. Roy. Soc. Lond. B 267: 1657-1662.

SMITH, R.K., MARAIS, A., CHADWICK, P., LLOYD, P.H. \& HILL, R.A. 2008. Monitoring and management of the endangered Cape mountain zebra Equus zebra zebra in the Western Cape, South Africa. Afr. J. Ecol. 46: 207-213.

STORZ, J.F., BHAT, H.R. \& KUNZ, T.H. 2001. Genetic consequences of polygyny and social structure in an Indian fruit bat, Cynopterus sphinx. II. Variance in male mating success and effective population size. Evolution 55: 1224-1232.

TACHEZY, R., DUSON, G., RECTOR, A., JENSON,
A.B., SUNDBERG, J.P. \& VAN RANST, M. 2002. Cloning and genomic characterization of Felis domesticus papillomavirus type 1. Virology 301: 313-321.

VAHA, J-P. \& PRIMMER, C.R. 2006. Efficiency of modelbased Bayesian methods for detecting hybrid individuals under different hybridization scenarios and with different numbers of loci. Mol. Ecol. 15: 63-72.

VAN DYK, E., BOSMAN, A-M., VENTER, E.H., NEL, P.J. \& ZIMMERMAN, D. 2004. Detection of bovine papillomavirus DNA in sarcoids in the Cape mountain zebra (Equus zebra zebra). Proceedings of the faculty Day, Onderstepoort 58-58.

VAN DYK, E., OOSTHUIZEN, M.C., BOSMAN, A.M., NEL, P.J., ZIMMERMAN, D. \& VENTER, E.H. 2009. Detection of bovine papillomavirus DNA in sarcoidaffected and healthy free-roaming zebra (Equus zebra) populations in South Africa. J. Virol. Methods 158: 141-151.

WAPLES, R.S. \& GAGGIOTTI, O. 2006. What is a population? An empirical evaluation of some genetic methods for identifying the number of gene pools and their degree of connectivity. Mol. Ecol. 15: 14191439.

WATSON, L.H. \& CHADWICK, P. 2007. Management of Cape mountain zebra in the Kammanassie Nature Reserve, South Africa. S. Afr. J. Wildl. Res. 37:31-39.

WEIR, B.S. \& COCKERHAM, C.C. 1984. Estimating $F$-statistics for the analysis of population structure. Evolution 38: 1358-1370.

WRIGHT, S. 1978. Evolution and the genetics of populations, Vol. 4. Variability within and among natural populations. University of Chicago Press, London.

YUAN, Z.Q., NICOLSON, L., MARCHETTI, B., GAULT, E.A., CAMPO, M.S. \& NASIR, L. 2008. Transcriptional changes induced by bovine papillomavirus type 1 in equine fibroblasts. J. Virol. 82: 6481-6491. 